\title{
FROM CAUSE TO MOTIVE: A BERGSONIAN BACKGROUND TO CHARLES OLSON'S AESTHETICS
}

\section{Abdullah Qasim Safi Al Hadi ${ }^{1}$}

${ }^{1}$ Department of English / College of Education / The Islamic University / Iraq Email:abdullah_alhadi@iunajaf.edu.iq

Published at 01/08/2021

Accepted at 24/07/2021

\begin{abstract}
Henri-louis Bergson (1859-1941), one of the most influential French figures in the tradition of process philosophy or so-called continental philosophy in the first half of the twentieth century, and Charles John Olson (1910 - 1970), a scholarly and pedagogical poet in the second half of the twentieth century America, proposed similar theories on new humanism, namely the importance of man's physiology, immediate experience, and recognition. Charles Olsen's aesthetics has sparked wide controversy, with particular emphasis on Olsen's approved or known resources. This essay provides a detailed rebuttal of this preposition, namely the importance of Henry-Louis Bergson's concept of "conscious perception" for understanding Olson's radical concept of direct perception or "stance toward reality." Although Olson is not known to have read or reviewed Bergson's works, Bergson can be well regarded as an outstanding physiological precursor for Olson's project of restoring man's physiology to its position at the center of the world, freeing it from the will to power or memory of the past. Both Bergson and Olson prefer instantaneous experiences to received knowledge, and value histology over history. Thus, the essay simply shows some affinity between the philosopher Bergson and the poet Olson and how the latter has been a major force behind the creation of the many varieties of poetry and performance arts in the late twentieth century and early twenty-first century America.
\end{abstract}

Key Words: poetry of experience, attention, direct experience, histology, recognition. 


\section{هن السبب إلى الدافع: خلفية برجسونية إلى جماليات تشارلز أولسون}

\section{عبد الله قاسم صافي الهادي1}

1 قسم اللغة الإنجليزية / كلية التربية / الجامعة الإسلامية / العراق abdullah_alhadi@iunajaf.edu.iq بريد إلكتروني

\begin{tabular}{|c|}
\hline \\
\hline 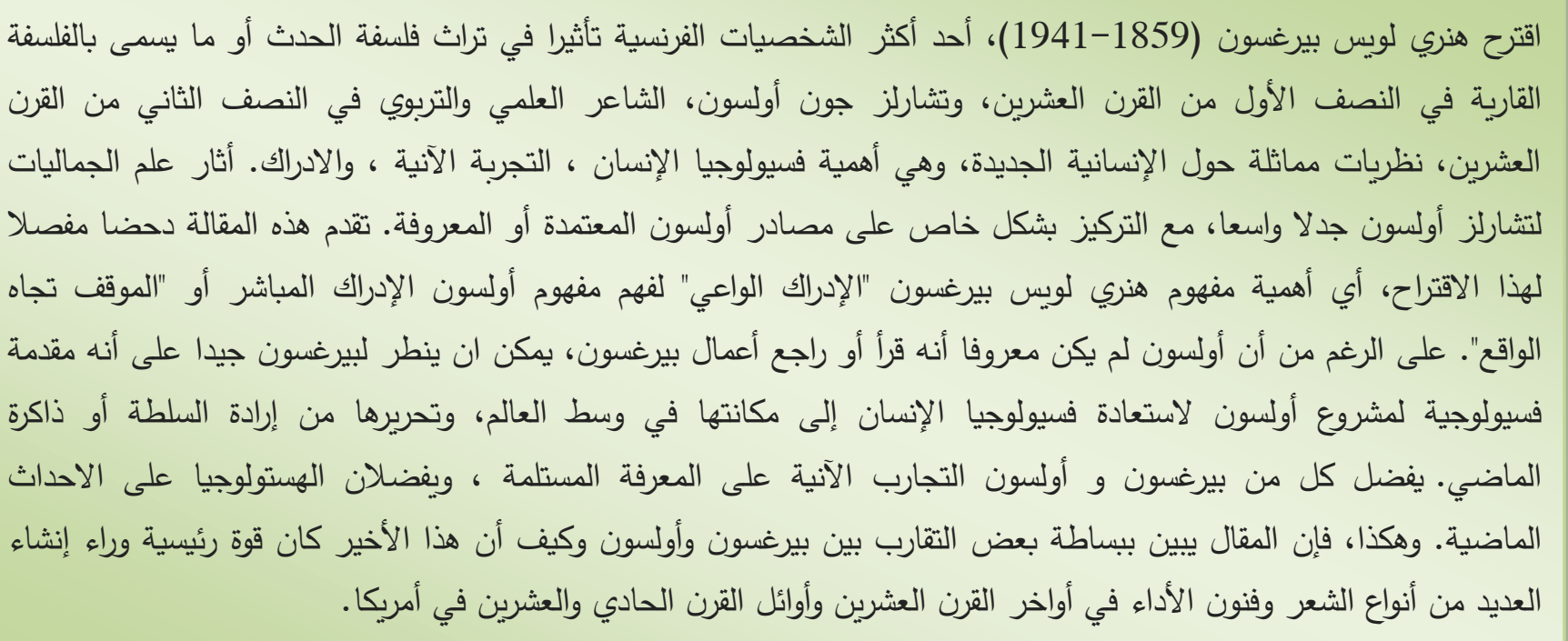 \\
\hline الكلمات المفتاحية: شعر التجربة، الانتباه، التجارب الآنبة، الهستولوجيا، الأدر اك. \\
\hline
\end{tabular}




\section{Introduction and Literature Review}

Charles Olson was such a scholarly and pedagogical poet in the mid-and-late twentieth century America to whom Robert von Hallberg devoted a critical study entitled Charles Olson: The Scholar's Art (1978) in which Hallberg traces Olson's relation to older scholars and poets, among them, Ezra Pound and William Carlos Williams. Other critical monographs are devoted by George Butterick and Ralph Maud which present a synthesis of resources. Such works are A Guide to Maximus Poems of Charles Olson (1978) by George Butterick; Charles Olson and Robert Creeley (1980 1990); Charles Olson's Reading: A Biography (1996) by Ralph Maud; Charles Olson and Frances Boldereff (1990) edited by Ralph Maud and Sharon Thesen; Charles Olson, Selected Letters (2000) edited by Ralph Maud. In fact, much has been said about Olson and the diversity of his resources but it's arguably that these studies are mainly based on what Olson himself revealed in his prose theory, speeches and interviews. In the matter of Olson's resources, Fredman (2010) suggests that one should "move beyond trends of thought represented in his [Olson's] library, in order to measure him against other significant figures and movements" (p. 1). But instead of tracing Olson's philosophy of perceptual experience back to its French origins, Fredman's counter-proposition was made to examine the American projectivism, therefore, Fredman arrives at a judgment, namely that the American pedagogical thinker John Dewey, who is known for his lectures "Art of Experience" (1934), is to be a precursor to Olson's attempt to merge art with experience.

One of the greatest modern philosophers whom Olson can advantageously encounter in discourse was the French Henri-Louis Bergson. Bergson preferred processes of momentary experience and perception to abstraction and science for apprehending reality. In 1922, Albert Einstein and Bergson debated the contemporary theorizing on the nature of time. Bergson censured Einstein's theories of relativity and time for being ignorant to the significance of intuition. Bergson is known for his strong preference for momentary experience and discernment as opposed to abstract rationalism of both the idealists and realists (Canales 2015).

Both Olson and Bergson criticized the psychologists and admired the metaphysicians. Both preferred instantaneous perception to received knowledge and past education or literacy. Both attempted to restore the human body, man's physiology as the center of the universe. Although Olson never referred to Bergson or was known to have reviewed his books, he was well aware of the French philosophy such as Merleau-Ponty (1908-1916) and his Phenomenology of Perception (1945). Olson (2010) emphatically announced that Merleau-Ponty's phenomenological research is a must to poets, at least to those included in Black Mountain College, because it focuses on experiences as primacy and, therefore, helps in their attack on the Western "completed thought" (p. 108).

\section{Discussion and Argument}

In "Human Universe" (1951), an essay details a new humanism that opposes relativism and determinist thoughts, Olson tries to advance some alternative to the whole Greek paradigm. After criticizing Socrates's generalizations and his readiness and enthusiasm to create a universe far away from discourse, and Aristotle's logic and 
classification, Olson cannot let Plato's idealism escape criticism. "Idealism," he says, is in the manner of Aristotelian logical methodology, "intervene[s] at just the moment they become more than the means they are, are allowed to become ways as end instead of ways to end" (Olson, 1997, pp. 156-157). This entails that Olson is proposing a new humanistic approach of openness as a surrogate for Western humanistic approach of completeness. Similarly, Bergson (2005) criticizes the idealists, as well as the realists, for reducing matter (the material world) to the perception which the modern man has of it and for making of it things that can produce his perceptions, but are essentially different from the nature of living perceptions (p. 9). Bergson and Olson share the idea that the idealists loose them (Olson and Bergson) and that they are no longer engaged because for them this is not what they know is the ongoing process of man's lived experience and because the idealists prevented man from participating in experience.

Bergson's ultimate vision in Matter and Memory is challenging fundamental assumptions of psychology, namely, that the brain generates representations and stores memories. Likewise, Olson (2010) criticized the psychologists for getting everything into the brain. Their model of the human brain, Olson says, is "to duplicate the human brain in model form would occupy so much space and involve so much money, way beyond space programs and way beyond sums of money" (p. 81)

If Socratesian proposition that "the body is nothing but a statue, or a machine" (qtd. in Guerlac, 2006, p. 18) made the significance of the body to be the main argument of Bergson's Matter and Memory, then Socratesian rule "I'll stick my logic up, and classify, boy, classify you right out of experience" (qtd. in Olson, 1997, p. 168) introduced the theme of the body that haunted Olson's works.

For Bergson, our perception helps us to act on the real, not to know it. Perception has to do with action and movement but not with knowledge. Human body is a living being that acts. Therefore, our brain is the heart of action rather than a center of knowledge. The brain is not a machine that produces representations of the material world from outside but an analytical instrument within the world acts as an action center that "appears to us to be an instrument of analysis in regard to the movement received and an instrument of selection in regard to the movement executed" (Bergson, 2005, p. 30) For the realists, the universe is an "aggregate of images" or objects governed by certain generated rules where there is no presence of personality. But then the realists realize that there are perceptions in which there is a privileged image (human body) to modify and transform the other images in the universe. While for the idealists, this privileged image is the center "by which the other images are conditioned." But while the idealists attempt to bridge the past with the present and predict the future, they find themselves "obliged to abandon this central position, to replace all the images on the same plane, to suppose that they no longer vary for him, but for themselves; and to treat them as though they made part of a system in which every change gives the exact measure of its cause" (Ibid., pp. 26-27) Olson's magnificent essay "Human Universe" is mostly concerned with man's relation to the universe. There are rules, Olson opens his essay, that is the human nature is already completely discovered and defined. Olson (1997) says that there must be "a discrimination" and "a shout." After this statement comes the question "was ist der Weg?", that is, what is the way?, its answer is that "we are ourselves both the 
instrument of discovery and the instrument of definition." Only through man's body "Der Weg stirbt," that is, the way springs (p. 155). Olson rejects the belief that unselectedness is "man's original condition." Brains, cells or skins respond to the external world or stimulus and make remarkable and useful decisions. "For it is man's first cause of wonder how rapid he is in his taking in of what he does experience" (p. 160-161). This is exactly what Bergson (2005) aims at: in contrast to other objects or images, which act according to the classical laws, man's body can act voluntarily, decide to respond to the external stimuli at a chosen time and space, and affect changes in the world around it. What characterize the body is novelty and reaction. The body is not a center of knowledge that produces representations but a center of action that transmits movements, therefore, changes our perceptions. Thus, the poor soul has gone, and the skin, the ralling point between body and the outer stimuli, is where all matter does take place. The engagement and involvement of man with the external reality is for man's purpose, that is, to restore to man some of his lost relevance.

Bergson's thesis states that the body acts as a conductor (receiver and transmitter) and "reflective perception" is an energy, "a circuit" in which "no disturbance starting from the object can stop on its way and remain in the depths of the mind: it must always find its way back to the object from where it proceeds" $(2005, \mathrm{p}$. 104). This bears a notable similarly to Olson's proposition that recognition is a circuit and the poem is an "energy discharge transmitted from where the poet got it... by way of the poem itself to, all the way over to, the reader" (Olson, 1997, p. 240)

For Bergson, the relation of perception to the external world of images is a relation of the part to the whole. In fact, the features of this relation are varied in number. First, this relation takes place outside our body because perception, unlike sensation or affection, which occurs in the body, occurs outside the body. Thus, perception of an object is different from the sense-organ, the body. Our perceptiveness is outside our sense-organ and our affectiveness within it. The outer objects apprehended by the body-subject, are in their nature rather in the body-subject, therefore our affections are accomplished in the body. There is an image system known as the physical world and the body is part of it. Second, the "Pure Perception" coincides with matter," the external world (Bergson, 2005, p. 57). In pure perception, we will come into contact with the reality of objects in direct vision (p. 58). Bergson is a phenomenologist as he prefers direct experience to inherited knowledge. He sees that perception is implied by the indeterminacy. Memory and Matter differentiates between automatic and voluntary responses. The complexity of the sensory system of organism guarantees the greatness of domain of indeterminacy that surrounds the action. The automatic response is interrupted by this indeterminacy, a delay of automatic response or action and finally a counter response or choice of action. From this indetermination, the relation between the subject-body and the impact of object-body or external objects is considerably varied. (p. 33) Thus, Bergson sees that perception is implied by the indeterminacy and the "variable relation" is a relation between the body (an animate being) and the inanimate objects or images inside the world (a multitude of images). The body is embedded in this material world and the relation between it and other bodies is variable because the body is the only part that is capable of taking action.

Similarly, Olson is also a phenomenologist. In his criticism of the Greek 
"UNIVERSE of discourse," he emphasizes direct experience and the two phenomenal universes: man and his natural environment. Moreover, the relation of perception to the external objects is a relation of part to the whole which occurs outside our body. Man's skin or "the meeting edge" and outer world are interrelated and they are better to be considered as a whole (Olson, 1997, pp. 156-161). This is Olson's new humanism or openness. Like Bergson, Olson believes that if man participates "in the larger force, he will be able to listen, and his hearing through himself will give him secrets objects share ... his shapes make their own way." In this regard, it is the act of projection, that is, the act of the artist in the large world of images or objects (Olson, 2010, pp. 132133). Olson criticized politics, theology, and epistemology because the adherents of these inventions destroyed man and his feature of being. These inventions imply that there is such a thing as knowledge. For example, Plato's invention of "Episteme" is harmful that made him lose "the Real" and involve the philosopher with resolution and complete idea. In addition, there is a tendency to treat political issues as the preferred target area, an ongoing condition, a tendency that is proved to have some faults in Olson's humanistic vision. The same is applied to theology. Man "inherited ... the idea that people should be helped... We have a very bad discourse system.' (pp. 86-88). This new doctrine of humanism and the zone of indeterminacy is complex in its initial stage. Olson's FIELD COMPOSITION, proposed in his essay "Projective Verse" (1950) as an alternative to the closed form or verse, is a zone of indeterminacy. This is surprisingly similar to the problem proposed by Bergson. Olson says:

This is the problem which any poet departs from closed form is specially confronted by. And it involves series of new recognitions. From the moment he ventures into FIELD COMPOSITION-puts himself in the open-he can go by no track other than the one the poem under hand declares, for itself. Thus he has to believe, and be instant by instant, aware of some several forces just now beginning to be examined. (Olson, 1997, p. 240, emphasis added)

Olson's direct perception and Bergson's immediate or instantaneous intuition meet in that both imply that man is the basic deal. In other words, Olson's emphasis on man's physiology, as the only accessibility of defining, discovering and participating in the experience, is the same as what Bergson emphasized, taking the human body as the center of action, making the pure perception different from everyone's perception. For both Bergson and Olson, the human body is the only living being that involves direct intuition, therefore, is able to select, act and take appropriate decisions. The entire universe is a process, and uncertainty paves the way for human response.

When Bergson (2005) proposes his theory of instantaneous recognition, he says that the body can act by itself, without the support of memory-image. It is a process of acting rather than representation. Recognition depends on motor activity and that it occurs physically. Rejecting memory, knowledge and past education, Bergson believes that man usually acts his recognition physically without or before thinking it. He thinks that the discovery of the world consists in what he calls the "primordial condition of recognition" (p. 92-95). This seems to imply that man should be illiterate. Literacy destroyed man and prevented and kept him from the real because it gives a complete representation of this world, which in fact, keeps man in distance from the objective reality. We can see a clear affinity between Bergson's and Olson's 
criticism of literacy and absence of activity. Olson writes that "[o]ne of the reasons why the whole thing blew up was that we have no activism." He admires Tim Leary's statement that we have to move from passive knowledge to the active experience, "we cannot examine anybody except in their being, in the context of their own place and behavior and pattern, and that's what the study of personality must be." All we need is participation and direct experience. Olson seems to reject the idea that man lives his life mimetically or has his experience by mimesis. Man must be "illiterate" because literacy is dangerous to the extent it prevents beings from hearing with their body and let them only listen with their mind. Olson narrates how he once tried to read some of his poetry of experience to literate people and angrily shouted at them "You people are so literate I don't want to read to you any more," and he stopped reading (Olson, 2010, pp. 106-107). If we are active, "it is exactly here where experience comes in that it is delivered back ... Man does influence external reality" (Olson, 1965, p. 11). Olsen believes that this is an era of consciousness, mushrooms, and instant experience, and the body is the only place that can resist mechanical destruction. In "Proprioception", as essay composed between 1959 and 1962 for the purpose of spanning the mushroom experience, Olson writes that our body is "the data of depth sensibility" as it is an "object which spontaneously or of its own order produces experience of, 'depth' Viz SENSIBILITY WITHIN THE ORGANISMBY MOVEMENT OF ITS OWN TISSUES" (Olson, 1997, p. 181). Louise Steinman (1986) claims that Olson's writings, especially "Proprioception," influenced many artists after him as he announced many times the "fundamental necessity of the integration of physiology and psyche. In his essay he remarks "that one's life is informed from and by one's own literal body, the gain being that movement or action is home" (p. 12).

In "The Resistance" (1953), an essay describes how the war had accomplished atomization and how man's physiology is the remaining instrument of resistance, Olson writes that our aim is to "regain what the species lost." Man has no alternative but his body (Olson, 1997, p. 174). War destroyed man and prevented experience and the only remaining ground to generate experience again is the body. The body is the source of new possibilities, new knowledge. In "Projective Verse," Olson prefers sense perception to reasoning. One perception should immediately lead directly to additional perceptions. Furthermore, in "Human Universe," he proposes clearly that the senses are capable of generating action, experience and finally art. The act of art is not description but enacting, and man has intentions and assumes hidden responsibilities to interrupt the entire chain of objects, images and actions. The pioneer of the encounter between being and the world is also his pioneer (Olson, 1997, p. 162).

Olson again meets Bergson in that our experience, action and art are not subjective and versions of our ego, but rather the involvement of active participation in the world. An interpenetration between the self and the world of images or objects. Olson interestingly cites from a French philosopher whom he does not name:

You are beyond the knower and the known, where there is no duality but only openness and unity, and great love. You not only see Truth, but you are Truth ... It is not an ego- inflating experience, but on the contrary, one which can help to dissolve the ego ... The conscious or awareness is expanded far beyond that of normal state. (Olson, 2010, p. 91, emphasis added) 
This is the meaning of "stance toward reality" in the "Projective Verse," that is, the self stands with all other objects and images rather that aloof from them. Rather than taking the movement of objectivism in which Ezra Pound and William C. Williams were involved, or its opposite, subjectivism, Olson prefers “objectism" as a more convincing methodology for the present-day uses. Objectism, Olson writes, "stands for the kind relation of man to experience." What's more, Olson also defines the term:

Objectism is the getting rid of the lyrical interference of the individual as ego, of the 'subject' and his soul, that peculiar presumption by which western man has interposed himself between what is as a creature of nature (with certain instructions to carry out) and those other creations of nature, which we may, with no derogation, call objects. (Olson, 1997, p. 247)

David Michael Levin (1988) discusses Martin Heidegger's book The Question of Being (1956) and considers it as a history of metaphysics, totalization, logocentricism and egocentricism. For Heidegger, Levine concluded, that nihilism essentially denies existence, and thus denies openness, expansion, and dimension. Heidegger believes that man is motive and accessibility, thus, the new humanism is open and man is the basic deal and the only measure. Thus, the purpose of the new humanism is essentially different from the attitudes involved in the will to power. By taking care of existence, we take care of ourselves and take care of our dimensions. Humanism should be a kind of care, attention and openness, that is, take care of yourself and existence (p. 23).

Bergson proposes two types of recognition: inattentive or what he calls "automatic recognition" or "recognition by distraction" and "attentive recognition." The former involves voluntary action, while the latter involves memory-images. The basic difference between the two is that in the former, our movement expands perception with the aim of extracting useful effects from it, thereby keeping us away from objects, however, what is perceived will lead us back to the object and stay on its outline (Bergson, 2005, p. 98). The continuation or expansion of perception is the essence of reactivating the process of motion recognition and attention recognition. Bergson's definition of automatic recognition as an extension of perception is comparable to Olson's principle of field composition that "FORM IS NEVER THAN AN EXTENTION OF CONTENT." Let's consider one of the magnificent passages from Olson's essay "Projective Verse":

ONE PERCEPTION MUST IMMEDIATELY AND DIRECTLY LEAD TO A FURTHER PERCEPTION. It means exactly what it says, is a matter of, at all points (even, I should say, of our engagement of daily reality as of the daily work) get on with it, keep moving, keep in, speed, the nerves, their speed, the perceptions, theirs, the acts, the split second acts, the whole business, keep it moving as fast as you can, citizen. And if you also set up as a poet, USE USE USE the process at all points, in any given poem always, always one perception must must must MOVE, INSTANTER, ON ANOTHER! (Olson, 1997, p. 247)

By origin, the doctrine "ONE PERCEPTION MUST IMMEDIATELY AND DIRECTLY LEAD TO A FURTHER PERCEPTION" is borrowed from the American activist Edward Dahlberg. By definition, the passage means that our perception 
changes and extends because we consist in movement, activity. Our perception is things rather than the reverse. That is, to focus on objects rather than concepts, on actual things rather than abstract features of things, and on action rather than on memory. The focus is on perception and attention where attention does not pursue the end of the perception is the extension and openness of perception. The focus here is attention and matter. In discussion of form as never than an extension of matter, Olson (1965) cites: "Matter as wise logicians say / Cannot without a form subsist; / And form, say I as well as they, / Must fail, if matter brings no grist" (p. 106). Olson writes that his main problem is undoubtedly attention itself, because it is more about changing the discourse system. Furthermore, the level of intensity must be equal to the occasion. "Equal, That Is, to the Real Itself" (p. 117, 122).

Now I would move to the crux of the matter that Bergson and Olson similarly try to emphasize: what is attention? What is the motive? Both propose that attention is not measurable such as increase in intensity, therefore, reducing it to something physical, it's not the object, and it's not directly the motive. Attention is man's positive quality that called by the object. Bergson (2005) defines attention as a "backward movement of the mind which thus gives up the pursuit of the useful effect of a present perception." Then, there are some movements set by the object or perception that give rise to a positive attention. By way of these movements, even their negative nature becomes positive where attention starts its course (p. 101).

After postulating the motor recognition, Bergson (2005) moves on to attentive recognition saying "[g]radual passage of recollections into movements. Recognition and attention. Here we come to the essential point of our discussion ... is it the perception which determines mechanically the appearance of the memories, or is it the memories which spontaneously go to meet the perception?" (p. 99). This is the crux of Bergsonian matter because the answer will determine the kind of relationship between brain and the memory, suggesting the connection between perception, attention and memory. The process of projection of memory-images is described by Bergson as follows: although external perception will cause us to move in its direction, the memory will guide the perception received the image of the memory, which is similar to itself and has been outlined by the movement itself. In this way, memory brings about and increases the current perception. When the saved image does not include detailed information about the perceived image, a projection is made to retrieve the deepest and farthest memory area until other known details are projected onto unperceived details (p. 101).

The context of this process, projection, association, transferences is apparently the motive. First, the object attracts attention in motion. Then attention begins to act on the object, transforming it through the ambiguous context, providing more possibilities and expanding perception, motive, so to speak. Throughout the process, attention behavior is not the cause, but the motivation. So what is the motive? Is it an object? of course not.

I will turn to Olson's admiration of French metaphysicians and his definition of attention. Olson admired the French metaphysician Maurice Merleau-Bonty who, like Bergson, focuses on the projection of memory-images and restoration of perception to 
its real position. Olson used to cite from Merleau-Bonty whose phenomenological studies on perception is valuable to Olson. Olson considered Merleau-Bonty's phenomenological aspects of perception as a "tremendous gain" to him and his poetics. Bergson's idea of attention or the process of projection or circuit, as not the cause but the motive, is itself has its counterpart in Merleau-Ponty. Olson (2010) quotes from Merleau-Bonty:

At the same time as it (the object) sets attention in motion, the object is at every moment recaptured and placed once more in a state of dependence on attention. It (the object) gives rise to the 'knowledge-bringing event,' which is to transform it (the object), only by means of the still ambiguous meaning which it requires that event to clarify, it is therefore the motive and not the cause of the event. (p. 109-111)

For Olson (2010), this is very interesting because it gets "the whole thing reversed, so that we don't have cause anymore; we have motive." Olson regrets that we are fooled by a complete universe of discourse for two thousand years where we have only cause while the motive is crapped. "We have lost motive almost entirely out of our mental capacity and have had cause instead." Man has been fooled by the objective world, therefore, it's time for the objective world to go away and apply a world of experience where our capacity and attention mobilize the original object. Finally, Olson substitutes the term "motive" with "attention." For him, attention is not something measurable, intensified or qualified. Man does not focus his attention. Attention is Man and vice versa, that is, Man is attention. The motive, for Olson, is neither the object nor attention but "the object that the attention does pick." In other words, the motive is the very moment that attention picks its object (pp. 110-112).

Attention is the quality of man that selects in the process of direct perception or direct experience. Both Bergson and Olsen suspected that we might be blinded by inattention to static results in terrible and vague vision. Attention is eternal, instantaneous. Bergson's (2005) conclusion that one should go under experience and attentive recognition and emphasize instantaneous perception, can be considered as a background to Olson's aesthetics because, for Olson, art springs out of experience. When Olson proposes his project of a postmodern epic in The Maximus Poems (1960, 1968, 1975), he writes that the epic "may itself be the result of an Indian experience which hadn't solidified itself before the longhouse" (p. 93).

Olson is known for his criticism of the Greek system, but one should not forget to points out that Olson criticized us as well. Olson writes that "it is not the Greek I blame" but ourselves as "we do not find out ways to hew experience as it is." Olson calls for our own direct method of defining and describing the world. Comparisons and symbols present deceiving inventions hiding and avoiding active mental states, metaphors and performance art. Rather than comparing, describing, and referring to the thing, Olson prefers calling attention to that thing, for the purpose of knowing its particularities (Olson, 1997, pp. 157-158). Man must start to change his position, a change that guarantees a change in the whole universe. When Bergson (2005) talks about the role of man in changing our perception of the universe, he writes that the structure of images, that is, our perception of the world can be completely changed by a very small change in a special distinctive image which is the body. This image lies in 
an intermediate area by which everyone else is conditioned, and through action everything changes like a kaleidoscope (p. 250).

Olson prefers the term histology to history as the later does not have any use anymore. He uses the verb "istorin" which "means to find out for yourself; and this is why I've been all over the goddamn Middle East and down into Egypt," and find out how it is possible to bridge cultures. Olson trusted Herodotus more than Thucydides. The former "goes around and finds out everything he can find out, and then he tells a story," While the latter is essentially narrating events. Olson regrets that we used to follow Thucydides rather than taking from Herodotus as a model. He cries, "we all go through this all the time, don't we? I mean, we have the Thucydidean." Olson criticized Thucydidean literature because it is based on war, and that battles are supposed to produce a new literature. One must be involved with histology (here and now) rather than history (the past). The past has no importance unless we recall it. It has no existence but in present and the "future can only happen now." Histology is creation of an event and it's relevant to each one of us. We must follow Herodotus who set out to discover how things actually go, and how things are described by those who hewed direct experience (Olson, 2010, p. 47-49). Histology means discovery rather than invention and putting an end to all sorts of divisions such as nations or cultures. Olson says that his aim is to link the civilizations and to "put an end to nation, put an end to culture, put an end to divisions of all sorts ... not the invention, but discovery of formal structural means is as legitimate as- is for me the form of action .... We have our picture of the world and that's the creation." (p. 132). This very Olson's project is done by attention or man, and his slogan is "Nowhere in man is there room for carelessness" (Maximus Poems, Letter 7, 36). Like fishermen, each one of us must look and pay much attention to space:

Eye,

\&polis, Fishermen, \& poets

Or in every human head I've known is Busy

Both:

The attention, and The care

However much each of us Chooses our own

Kin and Concentration

(Maximus Poems, Letter 6, 32)

Olson became a very influential figure in the second half of the twentieth century. For him, if man is the basic deal, then language is the prime of the matter. His focus on resistant language and jarred syntax and his objection to word-thought system led to a revolution in poetry and art performance emerged after him. Poets such as Jerome Rothenberg, David Antin, Clayton Ashleman, and Susan Howe resolved to hew experience in order to fulfil their cultural projects. Stephen Fredman (2010) wrote that the art of such poets is the art of performance and experience, employing "vernacular language ... as a vehicle to bring into present culture the fruits of their scholarly and physical excursions." Olson, found that vernacular language is the only language that 
"can be amalgamated with experience." They joined the Olsonian "project of making experience the ground of new cultural possibilities for an atomized world" (p. 11). Olson's project of performing and enacting rather than description, and his idea of the body as the locus for performance can be welled considered as a background for the performance art in the late twentieth century and the emergence of new philosophies such as Richard Shusterman's somaesthetics which centers on calling attention to bodily experience and the importance of experience in aesthetic appreciation, that is, to improve and extend the individual perception and action (Shusterman, 2008, p. 11). Shusterman's emphasis on bodily experience and the importance of philosophy as way of life accords with Olson's emphasis on direct experience which leads to radical philosophy from which the best form of art, especially the epic, may emerge.

Furthermore, Bergson's psycho-philosophical concerns and Olson's philosophical and artistic vision have been major forces behind the appearance of various performance arts in the late twentieth century. Fredman (2010) writes that Olson participated in what may be the first performance art created by John Cage at Black Mountain College in 1952. Following Olson, artists focused on the importance of the body in experience (p. 11). Performance shows the potential of man. Olson speaks on Maximus the figure and body who is "either me[Olson]" or a 2nd-century dialectician, "the navel of the world" (Olson, 2010, p. 15). This corresponds exactly to Bergson's proposition that "if my body is an object capable of exercising a genuine and therefore a new action upon the surrounding objects, it must occupy a privileged position in regard to them (Bergson, 2005, p. 20). Olson created a major factor in the appeal of the New Age. In describing the stories of Oprah Winfrey, Eva Illouz (2003) writes that "Oprah enjoins us to experience our own self in a richer way, from which transformation of self and others will ensure" (p. 131). But while Illouz takes from the 1970s documentary media in Britian as a background to Oprah Winfrey, I would suggest that Winfrey does not need to look for resources outside the United States and its precursor France. The influence of French philosophy on American art is a long story, and that Olson's great presence in the next generation has been overlooked by Illouz. Process philosophy went on to influence a lot of people and there has been even a continuous dialogue between philosophers and scientists. This where philosophy, literature and science meet in an incredible way-proving that everything is interconnected.

\section{Conclusion}

Charles Olson was an important poet and philosopher in mid-twentieth century America who admired and applied the French phenomenological philosophy of perceptual experiences. Although the origin of Olson's esthetics has been traced back to British mainstream schools, modernist American poets and American prohjectivists, however, Olson is indebted to French psycho-philosophers of perception. This paper provided a detailed discussion showing a close affinity between Charles Olson and the French Henry-Louis Bergson. Based on some valuable excerpts from both Bergson's Memory and Matter and Olson's prose theory and poetry, the paper argued that Olson's theory of attention and his art and poetics of experience has its origin in the critical aspect of late nineteenth and early twentieth century French culture of 
philosophy and psychology. Therefore, Bergson's theory of perception, that is, the universal image system and the position of human beings as the center of this system, is to be considered as a background for Olson's theories of direct perception, attention and openness, as well as the centrality of man and primacy of language. In addition to this affinity and influence, the paper emphasized that both Olson and his physiological precursor, Bergson, are responsible for much of the late twentieth century American performance art and experimental poetries. By using this conclusion, one can proceed with analyzing and describing various modes of French influence on contemporary American art through the lens of the phenomenological philosophy of perception.

\section{References}

Canales, Jimena (2015). Physicist and the Philosopher: Einstein, Bergson, and the Debate That Changed our Understanding of Time. Princeton:

Princeton University Press.

Bergson, Henri (2005). Matter and Memory. N.M Paul and W.S. Palmer (Eds.).

New York: Zone Books.

Fredman, Stephen (2010). Art as Experience: A Deweyan Background to Charles Olson's Esthetics. Journal of Philosophy: A CrossDisciplinary Inquiry, 6(13), 2010.

Guerlac, Suzanne (2006). Thinking in Time: An Introduction to Henri Bergson. Ithaca, NY: Cornell University Press.

Hallberg, Robert von (1978). Charles Olson: The Scholar's Art. Cambridge:

Harvard University Press, 1978.

Illouz, Eva (2003). Oprah Winfrey and the Glamour of Misery: An Essay on

Popular Culture. New York: Columbia University Press.

Levin, David Michael (1988). The Opening of Vision: Nihilism and the

Postmodern Situation. New York: Routledge, Chapman \& Hall Inc.

Olson, Charles (1997). Collected Prose. Donald Allen and Benjamin

Friedlander (Eds.). London: University of California Press. (1965). Human Universe and Other Essays. Donald Allen (Ed.).

San Francisco: Auerhahn Society. (2010). Muthologos: Lectures and Interviews. Ralph Maud

(Ed.). Vancouver: Talonbooks. (1983). The Maximus Poems. George F. Butterick (Ed.).

Brekeley: University of California Press.

Shusterman, Richard (2008). Body Consciousness: A Philosophy of

Mindfulness and Somaesthetics. Cambridge: Cambridge University Press.

Steinman, Louise (1986). The Knowing body: Elements of Contemporary

Performance and Dance. Boston: Shambhala Publication. 